\title{
AN INTRODUCTION TO THE TAX RECOVERY ACT
}

\section{DON J. MANDERSCHEID*}

The Tax Recovery Act governs the collection of property taxes by a municipality in the event that a property owner fails to pay the required taxes. This article describes the implications under the Act for failing to pay property taxes, and then, examines the procedures under the Act that must be followed by the municipality to recover overdue taxes. In examining the procedures in the tax forfeiture process, the writer describes the respective rights and remedies available to the municipality and the taxpayer. The writer then argues that while the Act appears to be well thought out, it contains several significant deficiencies. Specifically, the Act unclearly defines the respective rights of the municipality and the taxpayer in the following areas: fiduciary duty, public sale, final acquisition, private sale, redemption and contaminated liability. The writer then proposes improvements in each of these areas, and concludes that the most effective way to remedy the deficiencies under the Tax Recovery Act is to immediately create replacement legislation setting out a new scheme of tax forfeiture which incorporates all of the writer's suggestions. This will clear up any uncertainties, and therefore, decrease the amount of litigation in the area of property tax recovery.
La Loi sur le recouvrement de l'impôt régit la récupération fiscale par une municipalité quand un propriétaire foncier $n$ 'acquitte pas ses obligations. $L$ 'article décrit les conséquences juridiques que peut entraîner le défaut de paiement des taxes foncières et les procédures que doit suivre la municipalité au terme de la Loi. L'auteur examine les procédures de confiscation, les droits et mesures que la municipalité et le contribuable peuvent invoquer. Selon lui, bien que la Loi paraisse bien pensée, elle présente plusieurs lacunes. Les droits des deux parties ne sont pas clairement définis dans les secteurs suivants: obligation fiduciaire, vente publique, acquisition finale, vente privée, rachat et responsabilité relative aux propriétés contaminées. L'auteur propose des améliorations dans chacun de ces secteurs et conclut que la façon la plus efficace de remédier aux lacunes de la Loi consisterait à créer immédiatement une nouvelle loiqui inclurait toutes ses suggestions. Cette mesure permettrait de clarifier toute ambiguité et de diminuer le volume des litiges dans ce domaine.

\section{TABLE OF CONTENTS}

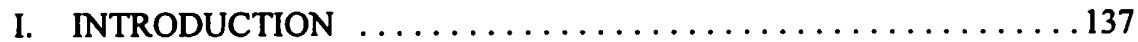

II. THE $A C T$ AND THE JUDICIARY $\ldots \ldots \ldots \ldots \ldots \ldots \ldots \ldots \ldots \ldots \ldots \ldots \ldots$

A. JUDICIAL APPROACH TO THE $A C T \ldots \ldots \ldots \ldots \ldots \ldots 140$

B. FIDUCIARY RELATIONSHIP $\ldots \ldots \ldots \ldots \ldots \ldots \ldots \ldots 14$

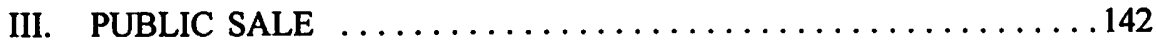

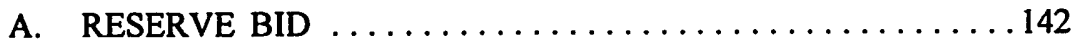

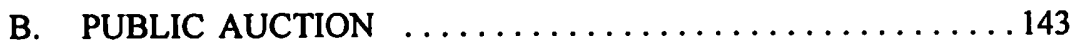

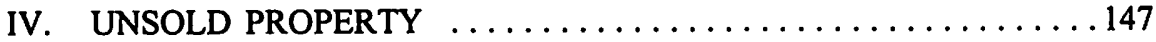

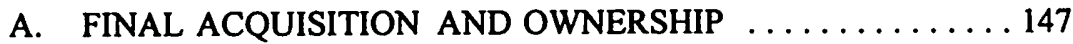

B. MANAGEMENT OF THE PROPERTY $\ldots \ldots \ldots \ldots \ldots \ldots 149$

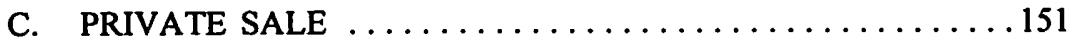

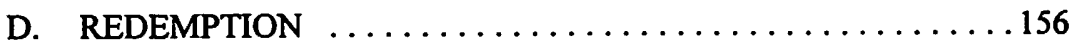

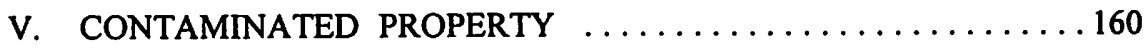

A. NEW ENVIRONMENTAL LEGISLATION $\ldots \ldots \ldots \ldots \ldots 160$

B.A., LL.B., LL.M., legal counsel, Office of the City Solicitor, Edmonton. I wish to acknowledge Ronald G. Hopp of the Faculty of Law, University of Alberta, for his expert guidance and advice in the preparation of this article. This article reflects the views of the author only. 


\section{B. EVADING LIABILITY $\ldots \ldots \ldots \ldots \ldots \ldots \ldots \ldots \ldots 1$ \\ C. ALTERNATIVE METHODS OF COLLECTION $\ldots \ldots \ldots \ldots 162$}

VI. CONCLUSION .............................164

\section{INTRODUCTION}

An anathema to the ownership of real property is the obligation to pay property taxes. A failure to pay traditionally results in the forfeiture of the property to the taxing authority. In Alberta, the taxing authority is the municipality. The remedies available to the municipality for collection of property taxes are primarily contained in the Tax Recovery Act.'

The Act is simplistic in composition. It is divided into two parts with the dividing point being the public auction. The first part deals with the municipality securing its interest in the property for the unpaid taxes. The second part is primarily concerned with the respective rights of the municipality, the taxpayer and other parties having an interest in the property. These parts create a step-by-step process which requires that certain acts be performed by various officials and authoritative bodies in accordance with stated time limitations. $^{2}$

The initial step in the tax forfeiture process as contained in the Act is the falling into arrears of the taxes for the property. Taxes are "deemed to be in arrears ... when they remain unpaid after December 31 of the year in which they were imposed..." or such later date which may be lawfully fixed for their payment. ${ }^{3}$ By definition, "'arrears' or 'arrears of taxes' includes all penalties for the non-payment of a tax, and also all costs and lawful expenses incurred or necessarily to be incurred by a municipality in respect of any parcel. ${ }^{4}$

When taxes fall into arrears, the municipality has the right to encumber the title to the property by registration of a tax recovery notification or caveat. ${ }^{5}$ Prior to this registration, the treasurer of the municipality is required to compile a tax arrears list in the month of March of each year. ${ }^{6}$ This list is comprised of all those properties where the taxes have been in arrears for more than one year, except for those properties which have a subsisting tax notification or caveat registered under any other tax recovery statute.?

R.S.A. 1980, c. T-1 [hereinafter $A c t$ ]. Alternative remedies will be discussed later in this article. See Krautt v. Paine, [1980] 6 W.W.R. 717 (Alta. C.A.) at 723, where Laycraft J.A. provides a brief but very concise overview of the tax forfeiture steps as contained in the Act.

Act, supra note 1 at s. 3(4).

Ibid. at s. 1(b).

The use of a caveat has not been in practice for a number of years and the only reference to a caveat in the Act is in ss. 3(1)(a), 4(2) and 20(1). In all other sections, the terms "tax notification" or "tax recovery notification" are used. The reference to a caveat would appear to be a carry over from previous versions of the $A c t$ which have been omitted during the repeal or amendment process.

Ibid. at s. 3(1).

Ibid. at s. 3(1)(a). From my research, I am unaware of any legislation, other than the Act, which would permit the recovery by the municipality of unpaid property taxes and the filing of a tax notification. The only explanation provided by the Act is in s. 41(1) which refers to proceedings taken under The Tax Recovery Act, 1922. Again, as is the case with the use of a caveat, supra note 5, this 
When the tax arrears list is completed, it must be posted for public viewing in the treasurer's office during office hours up to and including the date of the public auction. ${ }^{8}$ The tax arrears list is then forwarded to the Registrar of Land Titles prior to the first day of April. ${ }^{9}$ Upon receipt of the tax arrears list, the Registrar must place a tax recovery notification on the certificate of title for each property on the list, indicating that the property is subject to tax recovery proceedings under the $A c t .{ }^{10}$ The tax recovery notification can only be removed if its removal is directed by the treasurer or if "a certificate of title has been issued to the municipality or other person, under [the] Act."11

The existing certificate of title may only be cancelled with the consent of the treasurer or by devolution of the title by the operation of law. ${ }^{12}$ This prohibition safeguards the interest of the municipality in the property by ensuring that the property will not be sold without first addressing the issue of the outstanding taxes. ${ }^{13}$

Properties which are the subject of the registration of a tax recovery notification must be offered for sale by public auction prior to the expiry of three years from April 1 of the year of registration. ${ }^{14}$ However, such properties cannot be offered for public sale "until after the expiry of one year from April 1 of the year in which the tax recovery notification was registered." Is

The public auction is required to be advertised in the Alberta Gazette and in a newspaper having general circulation in the municipality. ${ }^{16}$ The advertisement must adequately describe the properties which are to be offered for sale and must "specify the place, day and hour at which the auction will begin [as well as] the conditions of the sale...."17

provision is probably a carry over from previous versions of the Act and was omitted at the time of amendment or repeal.

Ibid. at s. 3(5).

Ibid. at s. 3(3).

Ibid. at s. 4(1).

Ibid. at s. 4(5). The issuing of a certificate of title to the municipality would be as a result of final acquisition pursuant to s. 20(1). The issuing of a certificate to a person would be by way of sale at either the public auction or by private sale in accordance with $\mathrm{s}$. 23(1). The removal by the treasurer of the tax recovery notification for any other reason is discussed elsewhere in this article, infra note 149.

Ibid. at s. 4(2).

13 Where a taxpayer wishes to sell the property which is the subject of the registration of a tax recovery notification and lacks the required funds to obtain a discharge, a consent of transfer is required. In these cases, the consent of transfer will permit the proposed sale to proceed, the registration of a mortgage and the payment of the tax in arrears from the mortgage proceeds. This process is effected through the imposition of trust conditions between the respective solicitors for the municipality, the vendor and the purchaser. Regarding the devolution of title "by the operation of law," I would assume that this is in reference to a transfer of the property to a beneficiary pursuant to the administration of an estate.

$14 \quad$ Act, supra note 1 at s. 9(1).

is Ibid. at s. $9(2)$.

16 Ibid. at S. 11(1).

17 Jbid. at s. 11(4). 
Properties which are not sold at the public auction will be finally acquired by the municipality upon the expiry of one year from the date of the public auction. ${ }^{18}$ These properties may be redeemed by any person within four years of the date of the public auction by payment of the taxes that are shown on the municipal records as being due, other than the taxes for the current year, and by payment of the costs incurred by the municipality. ${ }^{19}$

When a property is sold by the municipality, either by public or private sale, the sale proceeds are distributed in a specified order of priority in the Act. ${ }^{20}$ If after distribution, there remains a surplus, the municipality must place the surplus in a separate tax sale trust account. ${ }^{21}$ A party interested in the surplus must apply to the Court of Queen's Bench within ten years from the date of the final acquisition of the property by the municipality or within ten years from the date of the sale of the property if sold prior to final acquisition. ${ }^{22}$

In order for a party to obtain all or any portion of the surplus, the court must declare the entitlement of such a party. ${ }^{23}$ The court will disperse the surplus funds having regard to the priorities in which sale proceeds would be distributed in a foreclosure action. ${ }^{24}$ Upon expiration of the time limit for the making of an application, the surplus monies remaining in the tax sale trust account and for which no declaration has been made by the court shall form part of the general revenue of the municipality. ${ }^{25}$

On a cursory review of the $A c t$, one sees a statute which is apparently well thought out with precisely timed procedures. However, on closer inspection, the $A c t$ is revealed for what it is: a statute fraught with error and omission. Because the provisions of the Act operate as the sole determinant of the respective rights of the municipality and the taxpayer, it follows that the enabling legislation ought to ensure that these rights are clearly defined. ${ }^{26}$ As a means of ensuring such clarity, the Act is a dismal failure. When the initial legislation was passed in $1904,{ }^{27}$ it was probably sufficient for its time. Unfortunately, with the passage of countless repeals and amendments, the initial framework has been lost in statutory obscurity.

Ibid. at s. 20(1). The subject of final acquisition by the municipality is dealt with in more detail later in this article, infra note 74.

Ibid. at s. 22(1)(2). The right of redemption is only available if the property has not been sold, therefore, both a sale at the public auction and a private sale must be considered. The subject of the right of redemption is dealt with in more detail later in this article, infra note 122.

lbid. at s. 27.

Ibid. at s. 28(1).

Ibid. at s. 28(2).

Ibid. at s. 28(2)(b).

Ibid. at s. 28(4).

Ibid. at s. 28(7).

In both McCarthy v. Inuvik (Town of), [1990] N.W.T.R. 215 at 218 (S.C.) [hereinafter McCarthy] and Trans-West Developments Ltd. v. Nanaimo (City of) (1979), [1980] 3 W.W.R. 385 at 402 (B.C. S.C.) [hereinafter Trans-West], the Courts held that relief from forfeiture under any other statute was inapplicable to a tax forfeiture.

The Edmonton Charter, S.N.W.T. 1904, c.19. 
The growing awareness of the inadequacies of the Act may be attributed largely to the present economic climate. With the downturn in the economy there has been an increase in unpaid taxes, and consequently, in the number of tax forfeitures. ${ }^{28}$ This increase has brought about a corresponding rise in litigation concerning the rights and duties of the municipality in regards to tax-forfeited property.

In this article, I propose to discuss certain deficiencies and inefficiencies which are inherent in the Act, with particular attention to the following areas: fiduciary duty, public sale, final acquisition, private sale, redemption, and contaminated property. In the discussion to follow, it will become readily apparent to the reader that the Act requires immediate legislative attention.

\section{THE $A C T$ AND THE JUDICIARY}

\section{A. JUDICIAL APPROACH TO THE $A C T$}

Because the Act has the potential of permitting property to be taken without the owner's consent, it has been considered by some members of the judiciary as confiscatory in nature. ${ }^{29}$ The forfeiture provisions of the Act have been termed by certain members of the judiciary as "Draconian" ${ }^{30}$ in nature and as "legalized larceny". ${ }^{31}$ To guard against abuse by the municipality of its statutory power of forfeiture, the judiciary has tended to approach the $A c t$ and like legislation from a conservative standpoint and has used a strict interpretation approach. ${ }^{32}$

The records of the Tax Department of the City of Edmonton disclose that during the years 1982 to 1988 , there was a steady increase in the number of properties which were finally acquired by the municipality through tax forfeiture. I have no reason to suspect that the situation is different in other municipalities in Alberta. The City of Edmonton statistics are:

$\begin{array}{lc}\text { YEAR } & \text { NO. FINALL } \\ 1982 & 2 \\ 1983 & 3 \\ 1984 & 4 \\ 1985 & 8 \\ 1986 & 29 \\ 1987 & 55 \\ 1988 & 32\end{array}$

See Berlin (Town of) v. Grange (1856), 1 E. \& A. 279 (Court of Error \& Appeal) and Scragg v. London (City Of) (1867), 26 U.C.Q.B. 263. Contra, Atwell v. North Vancouver (District of) (No. 2), [1963] 42 W.W.R. 216 at 218 (B.C. S.C.) [hereinafter Atwell (No. 2)] and Bifrost (Municipality of) v. Houghton, [1918] 1 W.W.R. 797 at 802 (Man. C.A.) [hereinafter Bifrost].

30 Trans-West, supra note 26 at 402, and McCarthy, supra note 26 at 220.

31 See the statement of Munroe J. in Atwell v. North Vancouver (District of) (No. I), [1963] 42 W.W.R. 57 at 58 (B.C. S.C.). Contra, Bifrost, supra note 29 at 803.

32 See $O^{\prime}$ Brien v. Cogswell (1889), [1890] 17 S.C.R. 420 at 424 [hereinafter $O^{\prime}$ Brien]; Morguard Properties Ltd. v. Winnipeg (City of), [1983] 2 S.C.R. 493 at 507 [hereinafter Morguard]; Gray v. Langley (Township of (1986), [1987] 2 W.W.R. 157 (B.C. C.A.) at 172 and Shaw v. Youngstown (Town of), [1928] 2 W.W.R. 310 (Alta. S.C.T.D.) [hereinafter Shaw]. 


\section{B. FIDUCIARY RELATIONSHIP}

As a consequence of this conservative attitude, early judicial decisions tempered the harshness of tax forfeiture legislation by imposing a duty of care on the municipality regarding the defaulting taxpayer and the affected property. ${ }^{33}$ This duty of care created a "fiduciary relationship" between the municipality and the defaulting taxpayer. By this relationship, a municipality was required to exercise its statutory powers in a manner which would not cause damage or loss to the defaulting taxpayer, other than that which was contemplated by the enabling legislation. ${ }^{34}$

In Massingberd v. Montague, ${ }^{35}$ Vankoughnet $\mathrm{C}$. aptly stated this duty of care and its attending fiduciary relationship in the following way:

The law has ever required that those, whose persons or property have been by misfortune or otherwise subjected to its process, shall be dealt with fairly and without oppression, and with as little suffering and loss as possible, and it throws this duty upon the officer charged with the execution of that process. The statute regulating sales of land for taxes, recogni[z]es and enforces this duty, for it provides that, "the sheriff shall sell by public auction so much of the land as may be sufficient to discharge the taxes, and all lawful charges incurred in and about the sale and the collection of taxes, selling in preference such part as he may consider it most for the advantage of the owner to sell first." The legislature have therefore not been less careful to guard against the sacrifice of property subjected to burdens for the public, than the law has always been to protect, against wanton waste and loss, property subjected under judicial process to the claims of individuals. Nor should they have been.

Taxes are at all times onerous, and are imposed merely from public necessity, and it is the policy as well as the interest of the state that they should bear as lightly as possible on individuals, and it is the duty of those charged with the collection of such charges, to maintain this policy so far as is in their power. ${ }^{36}$

In Bailey v. Parkland $31,{ }^{37}$ Lieberman J.A. of the Alberta Court of Appeal confirmed the existence of the fiduciary relationship described by Vancoughnet $C$. in Massingberd. ${ }^{38}$ Bailey is the only case in Alberta on the matter of this fiduciary relationship. ${ }^{39}$ As a result, it is open to speculation as to the extent that this implied trust can or will be judicially applied.

When the initial tax recovery legislation was drafted, ${ }^{40}$ it did not consider the existence of a fiduciary relationship between the municipality and the taxpayer. This is

See Phillips v. Belleville (City of) (1904), [1905] 9 O.L.R. 732 (Div.Ct.) [hereinafter Phillips] and Henry v. Burness (1860), 8 Gr. (U.C. Ch.) 345 [hereinafter Henry].

Phillips, ibid. at 745.

(1862), 9 Gr. 92 (U.C. Ch.) [hereinafter Massingberd].

Ibid. at 93 [emphasis in original].

[1986] 45 Alta. L.R. (2d) 225 (C.A.) [hereinafter Bailey].

Ibid. at 227.

In McCarthy, supra note 26 at 226, the Court, without reference to Bailey, held that where the municipality had taken title, there was nothing in the tax recovery legislation to exclude the imposition of a constructive trust on the part of the municipality.

Supra note 27. 
also true of subsequent repeals and amendments. This omission causes the Act to be incompatible with the judicially imposed fiduciary relationship. In parts of the discussion to follow, the problems associated with this incompatibility will be discussed in further detail.

\section{PUBLIC SALE}

From the time that the municipality is entitled to register a tax recovery notification to the public auction stage, the Act is surprisingly clear as to the respective rights and obligations of the municipality and the taxpayer. This is not incomprehensible as few problems can be expected to arise where the applicable statutory provisions are mandatory and lacking in discretion. If the taxpayer fails to pay the property taxes, a neatly timed set of procedures will ultimately take the non-payment to resolution by public sale.

The possible deprivation of a taxpayer's property through public sale requires that the sale be conducted in strict compliance with the formalities of the enabling legislation. ${ }^{41}$ Regrettably, the $A c t$ falls short of providing any clear direction in this regard.

\section{A. RESERVE BID}

For the purposes of the public auction, the municipality is required to set by resolution a minimum sale price for all properties which are to be offered for sale. ${ }^{42}$ Once set, this minimum price is termed the reserve bid, and it will mark the lowest amount that the municipality will accept for the property.

To ascertain the reserve bid, the treasurer or any person authorized by the council may enter on the property. ${ }^{43}$ Certain members of the judiciary have gone as far as to hold that in determining the reserve bid, it is the municipality's duty to fully apprise itself as to the state of the property. ${ }^{44}$

In Massingberd, Vankoughnet C. described this duty of inspection in the following words:

The writ for the sale of these lands is placed in the sheriff's hands, at least three months before the time of the sale, and it is not too much to expect that during that time he shall take such pains to make himself (S.C.C.) [hereinafter Standard Trusts Co.]. see Taber (Town of) v. Downer, [1923] I W.W.R. 1386 at 1387, (Alta. S.C.T.D.). an appraisal, but in addition, for the purposes of such appraisal, to carry out soil tests and an environmental assessment of the property. 
acquainted with the condition and value of the land about to be sold; and the machinery of his office would seem adequate for the purpose at very little trouble or cost. He can hardly excuse himself by total ignorance, when there is imposed upon him the exercise of judgment in selling first that portion of the land which he considers it most for the advantage of the owner to sell. ${ }^{45}$

Aside from any legal obligation, it would be prudent on the part of the municipality to conduct an on-site appraisal of the property prior to the public auction. This caution is justifiable, if only for the purpose of ensuring that the municipality does not acquire property which, by its state, is a liability and not an asset.

The Act does not specify a particular formula or set of rules for determining the reserve bid. Nevertheless, whatever means the municipality chooses to employ, the reserve bid must be arrived at in a manner which is unambiguous and requires no clarification. ${ }^{46}$ There is no requirement in the $A c t$ that the reserve bid be reflective of market value or that the municipality obtain the highest possible price. In addition, the case law is unclear as to whether there is such a requirement. Some cases impose a requirement, others differ. ${ }^{47}$ For example, in Excelsior, Boyd C. stated:

The test to be applied is not that of obtaining the fair market value as upon an ordinary business transaction, but how much may be expected upon an enforced sale by a public official. The statute does not speak of a fair sale, but of a "sale fairly and properly conducted." It is so conducted when it has been properly advertised, when a sufficient number of bidders attend to satisfy the judgment of the officer, reasonably exercised, when everyone has an equal chance, and when, there being no evidence of collusion or pre-concerted action in the audience, the highest bid or the only bid prevails: Eagleton v. East India Co. (1802), 2 B. \& P. 55; Metropolitan Street R Co. v. Walsh (1906), 94 S.W. Repr. 860. ${ }^{48}$

The line of thought as set out in Excelsior directly conflicts with Bailey and the decisions which support the existence of a fiduciary duty towards the tax-forfeited property. If the doctrine of stare decisis remains applicable, it could be assumed that a court faced with the determination of the issue of market value versus highest bid would follow the reasoning of the Court of Appeal as set out in Bailey. The reserve bid and the ultimate sale price would therefore have to equal the fair market value of the property. ${ }^{49}$

\section{B. PUBLIC AUCTION}

In the tax forfeiture process, the placing of the property for sale at the annual public auction is perhaps the single most important step. The public auction must be conducted in a manner which will ensure that all participants have knowledge of the rules of the

is Massingberd, ibid.

46 See Beltz v. Calgary (City of), [1960] 31 W.W.R. 134 at 136 (Alta. S.C.).

47 Phillips, supra note 33 at 750 , where Meredith J. stated: "there may have been many reasons why the highest price might not mean the best sale." Contra, Henry, supra note 33 at 357.

48 Excelsior, supra note 44 at 158.

49 In any event, taking into consideration this fiduciary duty, the municipality would be required to ensure that the property was not sacrificed at the public auction, Massingberd, supra note 35 at 93. 
public auction as set by the municipality. ${ }^{50}$ These rules equate to the conditions of sale by which the municipality will sell the property. ${ }^{31}$

Pursuant to s. 12 (1)(b) of the $A c t$, the municipality is required by resolution to set the conditions of sale. There is only one restriction in the $A c t$ concerning these conditions of sale and that restriction is found in $s .9(5) .{ }^{52}$ The conditions of sale are required to be conveyed by the municipality to the buying public at the time of the public auction..$^{53}$ If the conditions of sale are not strictly complied with, the resulting sale could be considered by a court as a nullity. ${ }^{54}$ In Cartwright, McLellan L.J.S.C., in reference to Denis v. Morinville (Town of), ${ }^{s 5}$ stated this conclusion:

There, as here, the highest bidder did not have the cash to complete the sale, he being ignorant of the condition that the sale was to be for cash. It was held there was no concluded sale, and the case is helpful in affirming that one who does not comply with the terms of sale cannot insist on the sale being completed to him. ${ }^{\text {s6 }}$

If a property sells at the public auction, the municipality may transfer the property to a purchaser by a transfer in the form prescribed by the $A c t .^{57}$ Prior to issuing a certificate of title, the Registrar of Land Titles must be satisfied that the notice required to be given to the registered owners, caveators, holders of builders' liens, and mortgage and encumbrance holders has been given. ${ }^{58}$ If this has not been done, the Registrar is required to give the notice in accordance with a substituted time period and cannot issue a certificate of title until this new time period has expired. ${ }^{59}$

See Cartwright v. West Hants (District of) (1979), [1980] 10 R.P.R. 69 at 73 (N.S. S.C.) [hereinafter Cartwright] where McLellan L.J.S.C. refers to the rules of the auction.

Ibid. at 74.

Pursuant to s. 9(5) of the $A c l$, every parcel that is offered for sale at the public auction, where some person is residing on or is in actual occupation of that parcel, shall be offered on the express condition that no sale shall have any force or effect unless and until it has been approved by the Minister. This requirement also applies where the parcel is being offered for sale by a municipality other than a city or town. See High Level lnvestments Lid. v. First City Trust Company and Edmonton (City of), [1990] 74 Alta. L.R. (2d) 274 (C.A.) [hereinafter High Level Investments], where the Court recognized that the municipality could sell a parcel of tax-forfeited property subject to the fulfilment of an express condition precedent.

Cartwright, supra note 50 at 73.

See ibid. at 76 and Denis v. Morinville (Town of), [1917] 2 W.W.R. 323 (Alta. S.C.) [hereinafter Denis].

Denis, ibid.

Supra note 50 at 76.

Act, supra note 1 at s. 23(1). Please note that the form of transfer as required pursuant to s. 23(1) is prescribed by Alta. Reg. 496/81 and is termed a Form "B" transfer. This form of transfer differs from the traditional transfer as provided in the Land Titles Act, R.S.A 1980, c. L-5 [hereinafter Land Titles $A c t]$. The only exception to the use of the Form "B" transfer is found in s. 23(2) of the Act which requires the use of the form of transfer as provided by the Land Tilles Act. For the ramifications of using the improper form of transfer, see Pelletier v. Opal No. 578 (Mun. Dist. of), [1925] 1 W.W.R. 973 (Alta. S.C.) [hereinafter Pelletier].

Act, ibid. at s. 25(1). See Pelletier, ibid. at 980, where Stuart J.A. states the purpose of this form of statutory safety provision.

Ibid. at s. 25(2). 
Once a certificate of title is issued, it is conclusive proof of the compliance with all conditions precedent to the issuance of the certificate. The validity of such certificate cannot be questioned by a court except on the following grounds:

(a) that the sale was not conducted in a fair, open and proper manner;

(b) that there were no taxes whatever in arrears for which the parcel could be sold;

(c) that the parcel was not liable to be assessed for taxes. ${ }^{60}$

The effect of these three exceptions is to limit the right of the former owner or other aggrieved parties, including caveators and mortgage and encumbrance holders, to contest the validity of a certificate of title which has been issued under the Act. These exceptions may further affect the interest of a purchaser or any party deriving an interest from such a purchaser by permitting their interest to become subject to impeachment. In cases falling within these exceptions, notwithstanding the bona fides of the purchaser, the courts have not hesitated in striking down the sale. ${ }^{61}$

Section 23(5) provides one more example of an exception to the indefeasibility of title provided by the Land Titles Act. ${ }^{62}$ In Krautt v. Paine, ${ }^{63}$ Laycraft J.A. explained this exception to the indefeasibility of title provided in s. 23(5):

The certificate of title which is obtained by a purchaser of the land from a municipality at either public or private sale is issued under s. 23 of the Tax Recovery Act. Subsection (5) is therefore applicable to all transfers and presents three separate cases in which the purchaser's title is subject to attack. That is so whether or not the municipality has first taken title in its own name. There is, thus, an important exception to the indefeasibility of title provided by s. 180 of the [Land Titles Act], in favour of any holder of a title forfeited for taxes who is able to bring himself within any of the three exceptions specified. Apart from subs. (5) of s. 23, a purchaser who found a municipality registered as owner of the land could buy it in reliance on his position as a [bona fide] purchaser. His title would not be subject to attack by the holder of the title which was forfeited for taxes: Turta v. C.P.R. and Imperial Oil Ltd., [1954] S.C.R. 427, 12 W.W.R. 97, [1954] 3 D.L.R. 1. Where s. 23(5) of the [Tax Recovery Act] applies to a title, however, the purchaser, despite his [bona fides], has a title subject to attack under any of the three exceptions. This exception to indefeasibility, of course, applies only to titles issued under s. 23 of the [Tax Recovery Act]. Though a title issued under s. 23 may itself be subject to attack, it could be a good root of title for a subsequent [bona fide] purchaser for value under the [Land Titles Act]. ${ }^{64}$

In addition to the uncertainty of title once a certificate of title is issued, there remains uncertainty as to the rights of the municipality, the defaulting taxpayer and the purchaser before such issuance. Pursuant to s. 26(1) of the Act, prior to the sale or final acquisition

61 Pelletier, supra note 57; Standard Trusts Co., supra note 41 at 1069; Rush v. Pembina (Mun. Dist. of .[1927] 1 W.W.R. 215 (Alta. S.C.T.D.); White v. Inga and Pidgeon (Mun. Dist. of) (1928), [1929] 1 W.W.R. 172 (Alta. S.C.A.D.); and Shaw, supra note 32. Please note that some of these cases deal with previous versions of the present s. 23(5) of the $A c t$ and therefore, such versions may not include the exceptions as stated in the present s. 23(5). 
of a property, any person interested in the property may apply to a court claiming that the provisions of the Act have not been complied with. ${ }^{65}$ Because ss. 17 and 20(3) of the Act do not permit the municipality to sell the property by private sale until after final acquisition, the sale contemplated by s. 26(1) must be the public auction.

Because the right of application under s. 26(1) is only available if the property has not been sold, it is crucial to know at what point in time a property is considered sold. ${ }^{66}$ Is this date the date of the public auction, the date of the sale agreement or the date of the conveyance? This issue was dealt with at length in Standard Trust Company v. Stewart (Municipality of), ${ }^{67}$ where Clarke J.A. held that the sale date was the date of the execution of the agreement for sale and not the date of the actual conveyance. ${ }^{68}$ Clarke J.A. concluded:

The trial Judge holds that there is no sale until completed by transfer and therefore the tender was made before the sale. I am unable to acquiesce in this view. No doubt there are decisions on different statutes both ways. In some cases the agreement has been held to be the sale, in others the formal conveyance. I think in each case regard must be had to the terms and objects of the particular act in question, and that under the terms of the [Act] in question the agreement to sell constitutes the sale. If this is not so the municipality as vendor would be unable to fulfil its agreement with the purchaser to transfer the title and perhaps become liable for serious damages. I cannot think that the [Act] contemplates any such situation, and hold that upon the true interpretation of the [Act] the sale is complete within the meaning of sec. 21 when a bona-fide agreement has been made to sell to a purchaser at the auction sale authorized by the [Act]. ${ }^{69}$

Pursuant to s. 26 of the Act, any interested party in the property may, prior to its sale or final acquisition by the municipality, apply to the Court of Queen's Bench. On receipt of an application, if the judge is of the opinion that the provisions of the Act have not been complied with, the judge may make an order directed to the Registrar. This order would "[stay] the issue of any certificate of title with respect to the parcel or the sale of the parcel, ...until the respective rights of the applicant and of the municipality have been determined by a declaratory order of the judge or until after the expiration of a period of [thirty] days or less, as fixed by [the] order." If the rights of the applicant and the municipality are not determined prior to the thirty day time limitation or on the time period fixed in the order, then the order ceases to be of any effect and no further order shall be made.

The judicial decisions which have dealt with such applications have been mainly concerned with procedural matters such as service of the notice or the posting of the notice. In this respect, see Excelsior, supra note 44; E.J.S. Holdings Ltd. v. Calgary and Ellmar Developments Ltd., [1982] 21 Alta. L.R. (2d) 384 (C.A.) [hereinafter E.J.S. Holdings]; Ompah Mines Ltd. v. Clerk of the Clarendon (the Township of) \& Miller, [1987] 43 R.P.R. 237 (Ont. S.C.) [hereinafter Ompah Mines]; Cresswell v. Speer, [1923] 1 W.W.R. 1250 (Alta. S.C.T.D.). See especially $O^{\prime}$ Brien, supra note 32 at 424. Pursuant to s. $1(\mathrm{~m})$ of the Act, the term "sale" is defined as including an agreement to sell. However, the term "sold" is not defined. In s. 9(4), the term "the date of the sale" or any similar expression is defined as meaning the date of the public auction. As this provision merely relates to the date when the public auction is held, it is of no assistance in determining the definition of the term "sold" as such term is used in the Act. Regarding the definition of the term "sale", see the judgment of Rinfret J. in Standard Trusts Co., supra note 41 at 1069. 
Notwithstanding the conclusion reached by Clarke J.A. in Standard Trust and my earlier comments in that regard, one might venture to suggest that the sale date might still become the subject of litigation. Given this possibility, the conditions of sale and resulting sale agreement could stipulate that the sale is subject to the right of the taxpayer or other parties interested in the property to redeem the property prior to the closing date. ${ }^{70}$ Justification for requiring such a condition lies in the fact that it is always more cost effective to permit the redemption to be carried out contractually prior to the closing date than to later debate the matter in court. ${ }^{71}$

\section{UNSOLD PROPERTY}

The fact that the property was not sold at the public auction does not end the matter between the municipality and the taxpayer. From the date of the public auction and thereafter, the municipality may acquire possession of the property, become the registered owner of the property, and dispose of the property by sale or lease. These rights and what they entail are not clearly set out in the Act. In the context of the municipality's ability to collect its outstanding taxes, this lack of guidance may create problems. This is especially true regarding tax-forfeited property which, due to its state, is a liability to the owner. ${ }^{72}$

\section{A. FINAL ACQUISITION AND OWNERSHIP}

If a property is not sold at the public auction, $\mathrm{s} .17$ of the Act requires that the Treasurer send a notice to every person whose name appears on the assessment roll as having an interest in the property, advising such persons as to what will transpire regarding the property. This notice will state that the property was not sold at the public auction; that the property will not be subject to sale prior to final acquisition by the municipality; that final acquisition will take place on the expiry of one year from the date of the public

Pursuant to s. 8 of the Act, the defaulting taxpayer may obtain a discharge of the tax notification by paying the outstanding taxes and costs prior to the date of sale. The term "the date of the sale" is defined in s. 9(4) of the Act as "the date upon which the sale by public auction is actually held." Pursuant to s. 22 of the Act, a property which is not sold at the first public auction may be redeemed by any person within four years of the date of such auction. If after the date of the public auction the required sale agreement has not been executed by the municipality and the purchaser, it could be argued that the property was not technically "sold", and therefore the right of redemption remained available to the taxpayer. The only possible way to circumvent this problem is to have the seal and the requisite signing authorities for the municipality available at the time of the public auction or to ensure that the documents are signed by all contracting parties on the date of the sale. Both of these solutions may not be feasible in larger municipalities.

In High Level Investments, supra note 52 at 276, Côte J.A. held that the municipality was at liberty to accept the purchaser's offer subject to a contractual condition precedent which mirrored s. 9(5) of the Act. This section requires the written consent of the Minister prior to a sale being deemed to have been concluded.

72 For a discussion of the effects of a contaminant (urea formaldehyde foam insulation) on the marketability and market value of a property, see $\operatorname{Re} 4$ Kingsfold Court, [1988] 38 M.P.L.R. 290 (Ont. Mun. Bd.) and Lantz v. Regional Assessment Commissioner, Region 21 (1983), [1984] 15 O.M.B.R. 299. 
auction; and that if the taxes are not paid prior to this date, the property is finally acquired and the municipality may sell the property without further notice. ${ }^{73}$

After the expiry of the one year time limit as prescribed by s. 17, all properties which have a subsisting tax recovery notification registered against their titles are finally acquired by the municipality. ${ }^{74}$ Upon final acquisition, the municipality may take title to the property and, by the wording of s. 20(1), "thereupon becomes the owner thereof," subject to the defaulting taxpayer's statutory right of redemption. ${ }^{75}$

From the date of final acquisition, whether or not title has been taken by the municipality, the municipality is entitled to exercise certain proprietary rights in the property. Pursuant to $\mathrm{s.} 20(4)$, the municipality may acquire possession of the property. ${ }^{76}$ In addition, pursuant to s. 20(3), the municipality may dispose of the property. It may be assumed that the right of disposition referred to in s. 20(3) is by way of sale because, pursuant to s. 29(1), it is not required that the municipality have finally acquired the property before it may lease the property to a third party.

The effect of final acquisition and its accompanying rights of possession and disposition creates an inference that the municipality is, for all intents and purposes, the legal and equitable owner of the property. ${ }^{77}$ This inference may prove to be a detriment

There is no rationale in the $A c t$ for imposing the one year sale freeze. If the $A c t$ gives the municipality the right to sell the property at the public auction, then should not such a right carry on after the public auction so as to enable the municipality to sell the property by way of private sale? This statutory restriction on the sale of property would appear to serve no purpose other than to impede the municipality's ability to collect its outstanding taxes and secure the property. In the interval, the party in possession may be committing serious waste to the property. Act, supra note 1 at s. 20(1).

The right of redemption is contained in s. 22(2) of the Act. The subject of redemption will be dealt with in more detail later in this article. It could be maintained that notwithstanding that title is issued to the municipality, until the statutory redemption period expires and the taxpayer is foreclosed from redeeming the property, the municipality merely holds an equitable interest in the property similar to that of a mortgagee under a mortgage. In such a case, the rights of the municipality in the property are temporary, and until the statutory redemption period expires, it is questionable whether or not the municipality could be labelled as the "owner", and therefore, liable for the property. In cases where the redemption period has expired, since as all of the rights of the defaulting taxpayer in the property are now vested in the municipality, it is immaterial whether or not the municipality has acquired the title to the property. See Castor (Town of) v. Fenton, [1917] 1 W.W.R. 1474 at 1486 (Alta. S.C.) [hereinafter Castor] where Stuart J. comments on the irrelevancy of the title being in the municipality's name.

$A c t$, supra note 1 at s. 20(4). Pursuant to s. 5(4) of the $A c t$, the municipality is entitled to possession of the property from and after the date that the property is offered for sale by public auction. However, because pursuant to s. 20(4) of the Act the municipality is entitled to possession from and after the date of its final acquisition of the property, these two particular sections would appear to be in direct conflict. Given such conflict, it is questionable as to which period of time, either the public auction or the final acquisition, the municipality is legally entitled to possession of the property. As to the municipality upon final acquisition becoming the legal and beneficial owner of the property, see Vulcan (Town of) v. Elves, [1935] 2 W.W.R. 587 (Alta. S.C.T.D.). However, a problem with this interpretation of the definition of the term "finally acquired" results from the wording of s. 20(1) which states that upon the municipality taking title to the property, it thereupon becomes the owner. As the legislature has chosen in s. 20(1) to denote ownership of the property with registration of the fee simple title, it could be argued that until such registration occurs, the municipality is not the 
to the municipality if the finally acquired property is required to be managed and maintained. In these situations, the Act does not contain rules of conduct for the municipality to follow. The $A c t$ has permitted the municipality to take the property from the control of the owner, but it abandons the municipality to its own discretion at this crucial point.

\section{B. MANAGEMENT OF THE PROPERTY}

The Act is virtually silent as to the extent of the municipality's duties and responsibilities regarding the management of tax-forfeited property. Although there are provisions in the $A c t$ which deal with when and for what duration the municipality may lease the property, ${ }^{78}$ or how and when the municipality may be in possession of the property ${ }^{79}$ there are no provisions which deal with the management of the property.

Questions immediately come to mind regarding the standards to which the municipality must adhere in the repair and maintenance of the property. As custodian of the property, is the municipality required to repair and maintain the property as would a prudent owner? Where agricultural property is forfeited, does the municipality have to farm the property as would a reasonable person? If the property is revenue producing, is the municipality obligated to seek out possible tenants for the property? ${ }^{80}$ These questions remain unanswered by the Act. To compound the situation, the available judicial decisions deal with specific fact situations and do not provide general rules for the management of taxforfeited property. ${ }^{81}$

In order for a municipality to be reimbursed for an expenditure made in the management of tax-forfeited property, the expenditure must be authorized by the Act $^{82}$ In an effort to provide direction as to the types of costs and expenses which may be recovered by the municipality, the Act uses the terms "prescribed costs", 83 "actual

"owner" for the purposes of liability. Compare the comments of Stuart J. in Castor, supra note 75. Pursuant to s. 29(1) of the $A c t$, the municipality may, prior to the expiry of the redemption period, lease the property for a term not in excess of one year and after the expiry of the redemption period, for any duration that the municipality considers appropriate. The statutory time restrictions contained in s. 29(1) of the Act cannot be exceeded by the municipality. See Shandro v. Eagle No. 81 (Municipal District of), [1946] 1 W.W.R. 505 at 509 (Alta. S.C.). Act, supra note 1 at ss. 5(4) and 20(4); see comments supra note 76.

In cases involving revenue generating property (i.e. apartment building, commercial property etc.), I question whether or not the municipality's fiduciary duty as trustee of the property would require the municipality to endeavour to lease the property so as to generate income and thereby reduce the amount of the taxes owed.

See Moisan v. Loretteville (Village of) and Moisan, [1941] 70 Que. K.B. 446 (C.A.) where the Court held that the municipality could not recover the cost of repairs where the repairs were made for sole purpose of making the property more marketable as a renting proposition and where the majority of the repairs were made to suit a particular tenant. 
costs $^{184}$ and "expenses lawfully incurred" ${ }^{85}$ These terms are either not defined in the $A c t$, or if defined, the definition is inadequate.

In s. $1(\mathrm{j})$ of the $A c t$, the term "prescribed" is defined as meaning "prescribed by the Minister". One may assume that the Minister would exercise this authority by way of a legislative regulation. Pursuant to s. 35 of the Act, the Minister may make regulations as he considers necessary for the proper carrying into effect of the provisions of the Act. To date, the only regulation which has been passed pursuant to s. 35 is Alta. Reg. 496/81 which deals with the various forms required by the Act.

Unlike the term "prescribed", the terms "actual costs" and "expenses lawfully incurred" are not defined in the Act. Presumably, the term "actual costs" would relate to costs actually incurred by the municipality. ${ }^{86}$ As for "expenses lawfully incurred", it could be assumed that for such expenses to qualify as being "lawfully incurred", they would have to be incurred pursuant to the authorizing legislation and could not be subject to hypothecation. ${ }^{87}$ Due to this lack of definition, it is uncertain for what costs and expenses the municipality may be reimbursed.

This statutory uncertainty may cause the municipality to be reluctant to expend monies in maintaining a property when there is no certainty of recoverability. This is especially true in cases where the outstanding taxes and costs exceed the property's market value. Since the equity of the defaulting taxpayer has been extinguished by the taxes and costs owing, it is impractical to expect that the property would ever be redeemed. Why, then, should the municipality be obligated to maintain a property when it will never be in a position to recover its outstanding taxes and costs from the property? In these situations, the municipality should be permitted to treat the property as if it were municipally owned, without the right of redemption applying. ${ }^{88}$

On the other hand, what is the position of the municipality where the taxes and costs owing do not outweigh the market value of the property? There may be incidents where, if the municipality refrains from carrying out the required maintenance, the property will deteriorate and its market value may be adversely affected. This factor, when combined with the municipality's implied fiduciary duty, may expose the municipality to liability to the taxpayer or other parties having a registrable interest in the property.

8s Ibid. at s. 27(1)(a). See also s. 1(b) of the $A c t$ where the terms "arrears" or "arrears of taxes" includes "all costs and lawful expenses incurred or necessarily to be incurred by a municipality in respect of any parcel." For a discussion of "expenses incurred or necessarily to be incurred", see The Queen $\mathrm{v}$. Marsham (1891), [1892] 1 Q.B. 371 at 379 (C.A.).

8s

See Neil v. British Columbia (Minister of Transportations and Highways) (1991), [1992] 46 L.C.R. 123 at 127 (B.C. Expropriation Compensation Board) and The Queen v. Marsham, ibid. at 376.

See Massingberd, supra note 35 at 93; The Queen v. The Governor and Guardians of the Poor of Kingston-On-Hull, [1853] 22 L.J.Q.B. 324 at 326 and Middlesex County Council v. Kingsbury Urban District Council, [1909] 1 K.B. 554 at 557 (C.A.).

See Castor, supra note 75. 
In order to avert liability, it could be argued that the municipality must act as would a reasonable person in the position of a manager of real property. At the very least, it could be assumed that the extent of the fiduciary duty must include an obligation on the municipality to repair and maintain the property so as not to cause the commission of waste. ${ }^{89}$ The Act should therefore allow any reasonable costs and expenses which are incurred by the municipality in the discharge of its fiduciary duty to be recoverable.

\section{PRIVATE SALE}

The Act permits the municipality to sell tax-forfeited property by way of private sale. ${ }^{90}$ Pursuant to s. 127 of the Municipal Government Act,${ }^{91}$ restrictions are placed on the sale of municipally owned property. For example, the municipal council lacks the statutory authority to sell municipal property for a sum which is less than the property's "fair actual value" or to dispose of land which was acquired for a public park, recreation grounds or exhibition grounds without advertising the sale in accordance with s. 324 of the Municipal Government Act. ${ }^{92}$ By the wording of s. 127, the restrictions on the sale of municipal property do not apply to property which was acquired pursuant to proceedings under the Act. Notwithstanding this exemption, the Act does impose restrictions.

The provisions of the Act which deal with restrictions on sale are confined to three specific situations. The first concerns the timing of when a property may become the subject of sale. ${ }^{93}$ The second concerns a prohibition of selling property to an auctioneer, councillor, or official of a municipality at a sale conducted by the municipality. ${ }^{94}$ The third involves the sale of occupied property. ${ }^{95}$ These restrictions apply to both a public or a private sale. Failure to comply with the particular restriction will void the sale. The first and second concerns are easily understood and require no discussion. This cannot be said for the third.

The Act requires that every property where a "person is residing or that is in actual occupation of some person," may only be sold by the municipality given the prior approval of the sale by the Minister. ${ }^{96}$ If it is determined that a person is residing or in the actual occupation of the property, then a by-law of the municipal council setting out

s9 Massingberd, supra note 35 at 93.

so Act, supra note 1 at $\mathrm{s} .18$.

9 R.S.A. 1980, c. M-26 [hereinafter Municipal Government Act].

92 For a discussion of the term "fair actual value" as used in 5. 127, see Spruce Grove v. Yellowhead Regional Library Board, [1985] 37 Alta. L.R. (2d) 70 at 77 (Q.B.).

93 As stated previously in this article, there are time limitations in the $A c t$ which specify when a property may be the subject of a sale. In this respect, see s. 9(1) of the $A c t$ which requires that all properties on which a subsisting tax recovery notification is registered shall be offered for sale by pubic auction before the expiry of three years from April 1 of the year in which the tax recovery notification was registered. Further, s. 17 of the Act requires that all properties not sold at the public auction will not be subject to sale prior to final acquisition, which is one year from the date of the public auction. Act, supra note 1 at s. $16(1)$.

9s Ibid. at ss. $9(5)$ and $18(5)$.

\% Ibid. 
the price, time, manner, terms and conditions of the sale is required.? The sale and the by-law will be of no force and effect until they have been approved in writing by the Minister. ${ }^{98}$ In all other cases, a resolution of the municipal council setting out the same particulars which are required in the case of a by-law is required.9

Whether a resolution or a by-law is needed is determined by the nature of the residency and occupation of the property. The Act does not provide a definition of the words, "a person is residing or that is in the actual occupation of some person". Since the Interpretation Act ${ }^{100}$ defines "person" as including a corporation, ${ }^{101}$ s. $18(5)$ of the Act is equally applicable to a corporation.

In the majority of cases, an on-site inspection of the property will be sufficient to ascertain residency or occupancy. However, in cases involving agricultural property that is being farmed seasonally, the task may not be so simple. ${ }^{102}$ Additionally, the position in regard to commercial property where a corporation is carrying on business is uncertain. Since a corporation may only conduct its business through a natural person, one would assume that a physical presence would not be required to support residency or occupation. ${ }^{103}$

The judicial decisions which have dealt with the terms "resides" and "occupation" indicate that such terms may not be subject to a common definition. ${ }^{104}$ In Newcastle City Council v. Royal Newcastle Hospital, ${ }^{105}$ Lord Denning explained the meaning of the term "occupation":

Ibid. at s. 18(5).

Note that pursuant to s. 9(5), the municipality is required to offer the property for sale "on the express condition that no sale effected thereof shall have any force or effect unless and until it has been approved in writing by the Minister." Pursuant to s. 20(3), any sale effected after final acquisition is subject to s. 9(5) and the approval of the sale by the Minister. Section 18(5) requires the passage of a by-law and "the by-law has no force or effect until it is approved in writing by the Minister under s. 18(3)." It is unclear why a private sale pursuant to s. 18(5) requires both approval of the sale and the by-law by the Minister, when, as is the case in s. 9(5), the requirement that the sale be approved by the Minister would equally suffice. I merely wish to point out, without justification or explanation, that the inconsistency between these two sections exists.

Act, supra note 1 at s. 18(4).

R.S.A. 1980 , c. I-7.

Ibid. at s. 25(1)(p).

See Re Hetherington, [1910] 14 W.L.R. 529 at 532 (Sask. Chambers) and Hart v. Rye, [1914] 16

D.L.R. 1 at 2 (Alta. S.C.).

See Qu'appelle Developments Limited v. Regina (City of), [1989] 5 W.W.R. 353 at 354 (Sask. C.A.) and Vancouver (City of) v. Coast Foundation Society (1974) (1991), [1992] 6 M.P.L.R. 311 at 315 (B.C. C.A.).

The range of possible cases which would qualify a property under s. 18(5) of the $A c t$ for a by-law and approval of the Minister are as numerous as they are diverse. Each case must, therefore, be determined on its own facts. See R. Ex Rel. Harding v. Bennett, [1896] 27 O.R. 314 at 319 (Chambers); The King v. Fredericton (City of) Assessors; Ex Parte Maxwell, [1917] 36 D.L.R. 685 at 689 (N.B. S.C.K.B.); Ottawa (City of) v. Nantel (1921), [1921-22] 51 O.L.R. 269 (C.A.); and Bentley v. Peppard (1903), [1902-03] 33 S.C.R. 444 at 445.

[1959] A.C. 248. 
But legal possession is not the same as occupation. Occupation is matter of fact and only exists where there is sufficient measure of control to prevent strangers from interfering, see Pollock and Wright on Possession in the Common Law, pp. 12,13. There must be something actually done on the land, not necessarily on the whole, but on part in respect of the whole. No one would describe a bombed site or an empty unlocked house as "occupied" by anyone: but everyone would say that a farmer "occupies" the whole of his farm even though he does not set foot on the woodlands within it from one year's end to another. ${ }^{106}$

In Re Kessler and Association of Professional Engineers of Ontario, ${ }^{107}$ Schroeder J.A., in commenting on the term "resides", stated:

Counsel for the appellant contends that "resides" is a word of flexible import which, under varying circumstances, can be given many meanings dependant upon the subject-matter and the object or purposes of the legislation in which it is used. In its primary sense the word denotes the place where an individual eats, drinks and sleeps, or where his family or his servants eat, drink or sleep: $R$. v. Inhabitants of North Curry (1825), 4 B.\&C. 953 at p. 959, 107 E.R. 1313. It was laid down in R. v. City of Fredericton Assessors, Ex Parte Maxwell (1917), 36 D.L.R. 685, that to "reside", in its ordinary legal interpretation, means to dwell permanently or for a considerable time, to abide continuously, to have one's domicile or home, to remain for a long time.

Where there is a doubt as to the legislative intent expressed by a word of such elastic significance as "resides", that doubt can frequently be resolved by examining the statute as a whole and reading one section or subsection in the light of another. ${ }^{\text {tos }}$

As the above quoted excerpts would indicate, the definition of the terms "resides" and "occupation" is dependent upon ascertaining the degree of control exercised by the party in possession and the intention of the legislation. ${ }^{109}$ Conceivably, given the wording of the $A c t$, a trespasser may qualify a property as one where "a person is residing or that is in the actual occupation of some person." As each case must be determined on its own facts, it is crucial that prior to a sale, the municipality be fully apprised of all elements of possession. In certain cases, this may not be possible without undertaking a constant day-

Ibid. at 255 .

(1970), [1971] 2 O.R. 43 (C.A.).

Ibid. at 45.

Sections $5(4)$ and $20(4)$ of the $A c t$ state that the municipality is entitted to possession of a property, and if resistance is encountered in obtaining possession, an order for possession and the written approval of the Minister must be obtained. These sections do not use the phrase, "a person is residing or that is in the actual occupation of some person." It may, therefore, be deduced that the terms "possession", "resides" and "occupation" are not synonymous. From my reading of these sections, it would appear that although a municipality may have obtained possession of a property, a person may still be considered to reside or be in occupation of the property. It just so happens that when the municipality entered on the property, there was no one physically present to resist. It could, therefore, be deduced that the intention of the drafters of the Act was not to require continuous physical possession of a property in order for a property to be considered as being where a person "resides" or is in "occupation". The requirement in ss. $9(5)$ and $18(5)$ would seem to exist to protect parties whose interest in the property, either by residency or occupation, may not be readily apparent on a physical inspection. For a discussion of the term "actual" with regard to occupation, see Mitchell $\mathbf{v}$. Johnson, [1918] 1 W.W.R. 785 at 792 (Co. Ct.). 
to-day surveillance of the property. This is impractical from the perspective of the municipality, given its limited resources.

In order to circumvent the possibility of an ultra vires transaction, the property should be deemed as qualifying for a by-law and approval of the Minister if it cannot be determined without reservation that the property is in an abandoned and vacant state. If there is reservation, the more cautious approach might be to require the sale to be made conditional upon the passage of a by-law and the approval of the Minister. Similar to the issue of redemption, it is more cost effective to deal with the issue on a contractual basis rather than to argue the matter before a judge. ${ }^{110}$

With the exception of the previously discussed restrictions on sale, where property is sold by private sale, the Act does not dictate as to a particular class of purchaser or the amount of the purchase price. "II Owing to this lack of statutory direction, there may be situations where the interests of the taxpayer and parties having a registrable interest in the property would be unjustly prejudiced. An example of such prejudice might be found where the period for redemption has expired and the taxpayer wishes to repurchase the property..$^{12}$ As the $A c t$ does not place a restriction on the amount of the purchase price, the municipality could set an unreasonably high price if only to increase the amount of its 5 percent commission as permitted by the $A c t .{ }^{113}$ Another example may be where a mortgagor purposefully permits the property to be placed for sale at the public auction and then buys it back for a fraction of its value. ${ }^{114}$

In order to rectify such injustice, the courts have intervened by the imposition of a constructive trust. ${ }^{115}$ In McCarthy, De Weerdt J. held that where the redemption period had expired and the taxpayer wished to reacquire the property, it would be unjust to permit the municipality to exact a purchase price which was greater than the outstanding taxes and costs. In coming to this conclusion, De Weerdt J. stated:

See text accompanying note 71 .

This lack of restriction as to purchaser and purchase price is equally applicable to property sold at the public auction. As discussed previously in this article, the fiduciary duty of the municipality towards the property would require the purchase price to be equivalent to fair market value: see text accompanying note 49 for a discussion of the amount of the purchase price. The position of the writer as stated therein is also applicable to tax-forfeited property which is sold by private sale. With regard to the purchaser, see Servais v. Shear (1928), [1928-29] 63 O.L.R. 381 at 383 (C.A.) where the Court upheld a sale of tax-forfeited property to a mortgagee of the property. See also Zelezniak v. Senkiw (1983), [1984] I W.W.R. 137 (Man. C.A.) where the Court upheld a sale of tax-forfeited property to a joint owner. Contra, Unsworth v. Grant, [1969] 1 O.R. 713 at 723 (C.A.) [hereinafter Unsworth] where the Court refused to permit a sale to a mortgagor.

McCarthy, supra note 26 at 226.

Act, supra note 1 at s. 27(1)(a).

See Unsworth, supra note 111 at 723.

See McCarthy, supra note 26 at 226 and Unsworth, ibid. at 723. Contra, Janisse v. Stewart, [1925] 28 O.W.N. 446 at 447 (T.D.) where Wright J. held that the purchaser of property at a tax sale who was a previous joint owner of the property was not a trustee for the other joint owner, nor did such purchaser occupy any fiduciary relationship to such party. 
The Municipal Act was silent as to beneficial ownership of the land by the municipality following a tax sale. The very possibility of redemption following such a sale suggests something less than an unconditional change of ownership. Where, as here, the municipality itself has taken title, there is nothing in the $A c t$ to exclude the imposition of a constructive trust in circumstances such as those of this case. The town has not materially altered its position since acquiring title to the land: see Storthoaks (Rural Mun.) v. Mobil Oil Can. Lıd., [1975] 2 S.C.R. 147, [1975] 4 W.W.R. 591, 55 D.L.R. (3rd) 1, 5 N.R. 23 [Sask]. ${ }^{116}$

In acknowledging this restriction of ownership on the part of the municipality, De Weerdt $\mathrm{J}$. was of the opinion that it would be unjust to deny the taxpayer restitution given the facts of the case. ${ }^{117} \mathrm{He}$ therefore declared that the town was to be the constructive trustee of the property for the benefit of the taxpayer, subject to payment by the taxpayer of the outstanding taxes, costs and interest. ${ }^{118}$ Although De Weerdt J. was prepared to impose a constructive trust on the municipality, he would not make an order requiring the retransfer of the property to the taxpayer. ${ }^{119}$

The imposition of a constructive trust has not been confined to the municipality. In Unsworth, Schroeder J.A. upheld the trial judge's decision imposing a constructive trust on the mortgagor-purchaser for the benefit of the mortgagee. The trial judge's decision was stated by Schroeder J.A. as follows:

The learned Judge rejected this contention and held that Muriel Grant having breached her covenant to pay taxes and other municipal rates and assessments had brought about a condition of affairs which

McCarthy, ibid.

Ibid. at 221. As the tax recovery legislation in issue in McCarthy did not contain a provision which permitted the payment to the taxpayer or other interested parties of a surplus from the sale proceeds after the expiry of the redemption period, its application to Alberta is limited. In this respect, the statute in McCarthy only dealt with the disbursement of a surplus prior to expiry of the redemption period. In Alberta, ss. 27 and 28 of the $A c t$ apply to a sale of property both before and after the expiry of the redemption period and the disbursement of the surplus after deduction of taxes and costs. If s. 28 of the Act were to apply in McCarthy, the municipality would not have been in a position at the time of sale (the ten year limitation as stated in s. 28(2)(a) of the Act not having expired) to appropriate for its own benefit any surplus from the sale proceeds after deduction of the outstanding taxes and costs. The municipality could therefore not be said to have been unjustly enriched at the expense of the taxpayer. However, where the ten year time limitation as stated in s. 28(2)(a) for application by interested parties for payment of the surplus held in the tax sale trust account expires, all interested parties are foreclosed of their rights to such surplus: see Household Realty Corp. v. Chatham (City of) (1988), [1989] 42 M.P.L.R. 215 at 218 (Ont. Dist. Ct.). In such a case, McCarthy would appear to apply if it were determined that there was a windfall to the municipality. McCarthy, supra note 26 at 226.

Ibid. at 227. De Weerdt J. was of the opinion that given the statutory and judicial restrictions, to make such an order would be to exceed the boundaries of the Court's jurisdiction. However, if the tax forfeiture statute was silent on the imposition of a constructive trust, yet the Court imposed same, as such statute is equally silent on a re-transfer of the property to the taxpayer after the expiry of the redemption period, could not the Court compel such re-transfer? Apparently, De Weerdt J. felt that since the town was willing to sell the property, the fact that the Court did not order such re-transfer should not cause a problem. However, what would be the case if the town was not willing to sell the property? The imposition by the Court of the constructive trust in the absence of an order compelling a re-transfer may not be of much use to the taxpayer. 
enabled her to obtain title to the mortgaged property, and applying the principle enunciated in New Zealand Shipping Co., Ltd. v. Societé des Ateliers et Chantiers de France, [1919] A.C. 1, he held that she was precluded from benefiting by her own wrong, and that she therefore held title to the property as trustee for the respondent mortgagee to the extent of his interest under the mortgage, and that she could transmit no higher title to the appellants than she herself possessed. ${ }^{120}$

Aside from any question of the amount of the purchase price, the identity of the purchaser or the purchaser's motives for acquiring the property, the courts have insisted that the bona fides of the purchaser continue at all times up to the time of the registration of the title in the purchaser's name. ${ }^{121}$

\section{REDEMPTION}

As stated in the Introduction of this article, property which has not been sold by the municipality may be redeemed by any person within a period of four years from the date of the first public auction. ${ }^{122}$ The right of redemption expires on midnight of the last day of the redemption period ${ }^{123}$ and cannot be extended by the municipality. ${ }^{124}$ To reach any other conclusion would permit the municipality to vary the provisions of a provincial statute - a power which only the provincial legislature may exercise. ${ }^{125}$

This lack of discretion will work a hardship against the taxpayer in cases where the amount of the taxes and costs owing is drastically less than the market value of the property. ${ }^{126}$ In such a case, provided the municipality has complied with the proceedings required by the $A c t$, a court will not order the municipality to sell the property back to the taxpayer. ${ }^{127}$ The justification for imposing such stricture was explained in the often quoted passage of Lamont J. in the case of Krumm v. Shepard No. 220 (Municipal District of $:{ }^{128}$

It was also necessary once an assessment was made, that no uncertainty should exist as to the right of the municipality to obtain the taxes levied (if unpaid) out of the land by forfeiture proceedings. That forfeiture proceedings are drastic and in some cases work hardship is beside the question. The Legislature in passing the Act no doubt foresaw the possibility of an owner being deprived of his land through non-payment of the taxes levied against it by reason of forgetfulness or inattention on his part, but it evidently concluded that a want of finality in reference to the assessment or a want of certainty as to the municipality's right

Supra note 111 at 719.

See Pelletier, supra note 57 at 980 and Soper v. Windsor (City of), [1914] 32 O.L.R. 352 at 367 (C.A.).

Act, supra note 1 at s. 22.

See Ray and Ray v. North Vancouver(the District of [1965], 52 W.W.R. 574 at 575, [B.C. Co. Ct.]. See Atwell (No. 2), supra note 29 at 217 and Moonshot Developments Ltd. v. Ontario (Ministry of Municipal Affairs) [1990], 49 M.P.L.R. 193 at 204 (Ont. S.C.) [hereinafter Moonshot Developments]. See Atwell (No. 2), ibid. at 220.

See McCarthy, supra note 26 and Moonshot Developments, supra note 124 at 204.

See $M c$ Carthy, ibid. at 227. In cases where the taxes owing on the property are less than the market value of the property and if the municipality has not entered into an agreement to sell the property or has not appropriated the property for its own use, why should not the right of redemption still apply?

[1928] S.C.R. 487. 
to recover the taxes out of the land, with its consequent derangement of the municipal finances, would be a much greater evil. ${ }^{129}$

When a redemption is requested and payment of the outstanding taxes and costs has been made, if the municipality has not finally acquired the property, the Registrar of Land Titles is instructed by the treasurer to discharge the tax recovery notification. ${ }^{130}$ If final acquisition has taken place and title is issued to the municipality, the treasurer will instruct the Registrar to revive the title together with all notifications, charges and encumbrances which the title would have been subject to had title not been issued to the municipality. ${ }^{131}$ This requirement is essential in order to protect all parties having an interest in the property and who, if not for the default in the payment of the taxes, would still have their interest registered.

In addition to the notifications, charges and encumbrances which previously existed against the title, s. 22(5)(b) of the Act provides that the defaulting taxpayer will take title subject to any estate, interest or encumbrance created while the property was held by the municipality. Presumably, the first part of this section is to protect the interests of a tenant under a lease or a grantee under an easement from the municipality. The latter part, which deals with encumbrances, is more difficult to interpret.

The Act does not define the term "encumbrance". Using the definition of "encumbrance" as provided in the Land Titles Act, ${ }^{132}$ such a term would include "any charge on land created or effected for any purpose whatsoever, inclusive of a mortgage, mechanics' or builders' liens ... and executions against land...." ${ }^{133}$ In practical terms, it is nonsensical to provide a right of redemption and yet permit the municipality to encumber the property by pledging the title for mortgage purposes. To arrive at such conclusion would totally defeat the rationale for the right of redemption.

To permit the municipality to encumber the property by a legal charge during the redemption period would be to provide the municipality with an alternative means of tax

Ibid. at 511.

Act, supra note 1 at s. 22(3).

Ibid. at s. 22(4)(5).

Supra note 57.

Ibid. at s. 1(f). In s. 23(6) of the Act, "every certificate of title issued under this section gives to the person or municipality to whom it is issued an estate in fee simple, ... free from all encumbrances except those..." stated in this section. It is interesting to note that the list of excepted encumbrances includes registered easements and instruments registered pursuant to section 72 of the Land Titles $A c t$; the rights of a purchaser on the instalment plan; and right of entry orders which have been registered under the Land Titles Act. These particular registrations do not fall within the definition of "encumbrance" as provided in the Land Titles Act. It could, therefore, be concluded that the term "encumbrance" as used in the Act was not intended to permit the municipality to charge the property as security for an indebtedness and that such term merely denotes the registration of an interest in the property. For a discussion of the meaning of the term "encumbrance", see Pflueger and Einnarson v. South Alberta Land Registration District, [1977] 2 Alta. L.R. 398 at 399 (S.C.), where Laycraft J. held that under the definition of "encumbrance" in the Land Titles Act, such a term means any charge on land, and because "the term 'charge' signifies that land is security for the payment of a debt or performance of an obligation," a surface lease is not a charge on land. He therefore concluded that a surface lease cannot be an encumbrance. 
collection. Should this be the intention of the legislature, then a provision should have been made in the $A c t$ requiring the municipality to discharge such encumbrances upon redemption. This is not the case with the present wording of the Act. It is submitted that this part of s. 22(5)(b) creates more confusion in an already too confused area and requires amendment.

In order to effect a redemption, the person redeeming need not have an interest in the property. ${ }^{134}$ The redeeming party must, however, be in a position to pay to the municipality all taxes that are shown on the municipal records as being due, other than taxes for the current year, as well as the greater of prescribed or actual costs incurred by the municipality. ${ }^{135}$

To place in perspective the problems associated with payment of the redemption monies and the expiry of the redemption period, consider the following hypothetical situation:

On the day of the expiry of the redemption period, the defaulting taxpayer attends at the office of the treasurer of the municipality and requests to redeem the property. The property is an apartment building with tenants and the municipality has received rents and expended monies in the management of the property. The taxpayer has entered into an agreement to sell the property, with the closing date being the immediate following day. As the property is revenue producing, the tax department is not in a position to provide an accounting to the taxpayer of the taxes owed, expenses incurred and revenue obtained. The taxpayer is advised that because this information is not recorded with the tax department, it must come from the managing department and this will take a few days. As required by the $A c t$, the municipality permits the redemption based on the available tax roll information. The taxpayer then completes the sale with the purchaser. Subsequent to the sale closing, the municipality completes its final accounting and adds expenses and revenues to the tax roll of the property. The net result is an increase in the amount of taxes owed. Under the Sale Agreement, the taxpayer/vendor was responsible for all taxes to the closing date. Upon being apprised of the amount outstanding, the purchaser seeks reimbursement from the taxpayer/vendor but is advised that he is now retired in Florida.

The state of affairs portrayed in the above hypothetical is not a rare occurrence. When faced with a similar situation, most practitioners are appalled to discover that the tax balance as recorded on the tax roll is subject to change, depending upon the final accounting. They are further distraught that the final accounting may take as long as a week and if the redemption period expires prior to payment of the redemption amount, the municipality is powerless to permit redemption after such expiry. ${ }^{136}$

In the hypothetical, if the taxpayer failed to redeem the property during the redemption period but still wished to regain title for the purposes of its intended sale, the Act will require more than just payment of the redemption monies. In order to reacquire title, the

See Re Gravestock and Parkin, [1944] I D.L.R. 417 at 420 (Ont. C.A.).

Act, supra note 1 at s. 22(1). See also, Ompah Mines, supra note 65 at 253, where Eberle J. held that the redemption "money must be tendered in the character of and for the purpose of redeeming the [property]."

See text accompanying note 124 . 
taxpayer would have to purchase the property by private sale from the municipality. As stated previously, on a private sale the municipality is entitled to a 5 percent commission from the surplus proceeds of the sale after deducting the outstanding taxes and costs. ${ }^{137}$ Since the property in the hypothetical is resided upon or in the actual occupation of a person, a by-law and approval of the Minister is required. If a mortgage or other financial encumbrance is involved, the interests of such parties in the property must be protected. This protection will require that the property be sold at market value. An appraisal from an appraiser not in the municipality's employ will therefore be required. ${ }^{138}$

To further complicate matters, the entire process from start to finish will, as a rule, take at least three months. When confronted with these possibilities, many practitioners have advised their clients to redeem the property and deal with the subsequent tax adjustment in the purchase and sale agreement. However, collection from the responsible party may prove difficult.

In order to address the problems identified in the hypothetical, the Act should be amended to extend the redemption period and permit a redemption of the property after the expiry of the initial four year period. This right of extension would only be available if the redeeming party has tendered to the municipality all taxes and costs recorded on the tax roll for the property. From the date of such tender, the municipality could then be given a specific period of time, for example, thirty days, to provide its final accounting. ${ }^{139}$ If, after such accounting, taxes and costs remain outstanding, the taxpayer could be given a similar period of time to pay. The expiry of this latter period would then conclude the period of redemption.

If there are costs which were not reported until after the final accounting, the municipality should be statute-barred from placing these costs on the tax roll. With regard to revenues which are reported after the final accounting, such revenues should be treated as surplus monies and the provisions contained in $\mathrm{s} .28$ of the Act will apply. In accordance with s. 28(1), these revenues would be placed in a tax sale trust account and any interested party would have the right, subject to the time limitations stated in s. 28(2), to apply for payment out of the trust account. ${ }^{140}$

Act, supra note 1 at s. $27(1)(a)$.

As a result of the potential problems stemming from Bailey, one may wish to obtain an outside appraisal. In doing so, any question that the municipality may have sold the property for a sum which was less than its fair market value may be lessened. In enlisting the assistance of an outside appraiser, the municipality could argue that it took all necessary precautions to safeguard the interests of the taxpayer and other parties having a registrable interest in the property. The costs of such an appraisal should be recoverable by the municipality pursuant to s. 27(1)(a) of the $A c t$ as constituting "expenses lawfully incurred".

This would be similar to s. 39 of the Law of Property Act, R.S.A. 1980, c. L-8, where the mortgagor or purchaser may require that the mortgagee or vendor provide within thirty days of request, a written statement setting out the amount of the principal, interest, any other charges owing and the balance in the tax account.

For a discussion of the manner in which surplus monies are paid out by the court, see In re Tax Recovery Act, In re Watson, [1946] I W.W.R. 667 (Alta. Dist. Ct.) and In re Tax Recovery Act; Barnum v. Williams, [1945] 3 W.W.R. 432 (Alta. Dist. Ct.). 
It is fundamental to every tax recovery scheme that the enabling legislation recognize the requirement for certainty in commercial transactions. Such legislation must ensure that the municipality is accountable for its actions. To hold otherwise would create uncertainty in the conveyance of real property. Perhaps to this end, the proposed amendment to the redemption provisions of the Act may achieve this goal.

\section{CONTAMINATED PROPERTY}

\section{A. NEW ENVIRONMENTAL LEGISLATION}

In relation to the tax forfeiture process, the subject of environmental contamination is only now receiving municipal attention. This late awareness is due in part to the fact that the effects of industry and commerce on the environment are only now being realized and in part by virtue of the recent passage of the Environmental Protection and Enhancement Act. ${ }^{141}$ This new environmental legislation now defines who the potentially liable parties might be. It is therefore extremely relevant to the municipality in regard to the acquisition of contaminated property through the tax forfeiture process.

By the wording of the new environmental legislation, a municipality, in acquiring ownership or possession of contaminated tax-forfeited property, could fall within one of the sections which attract liability. ${ }^{142}$ Under the new environmental legislation, the applicable definition of the culpable party may range from who is the "owner"143 of the property to the "person responsible for the contaminated site." ${ }^{144}$ Unfortunately, until

S.A. 1992, c. E-13.3 [hereinafter the "new environmental legislation"].

142 It could be argued that pursuant to $s .114(2)$ (b)(ii)(iii) of the new environment legislation, ibid., the Director could find the municipality liable if, at the time of setting the reserve bid, the municipality failed to conduct an inspection of the property and if it could be proven that such inspection would have disclosed the contamination. Section 114(2)(b)(ii)(iii) reads as follows:

114 (2) In deciding whether to issue an environmental protection order under subsection (1) to a particular person responsible for the contaminated site, the Director shall give consideration to the following:

(b) in the case of an owner or previous owner of the site,

(ii) whether the person knew or ought reasonably to have known that the substance was present in, on or under the site at the time that person became an owner;

(iii) whether the presence of the substance in, on or under the site ought to have been discovered by the owner had the owner exercised due diligence in ascertaining the presence of the substance before he became an owner, and whether the owner exercised such due diligence.

Pursuant to s. 1(rr) of the new environment legislation, ibid., the term "owner" is defined as meaning:

1(rr) "owner", with regard to land, means

(i) the registered owner of the land,

(ii) a purchaser of the land whose interest as a purchaser is shown on the certificate of

title to that land, or

(iii) a tenant or other person who is in lawful possession or occupation of the land.

Pursuant to s. 96(1)(c) of the new environment legislation, ibid., the term "person responsible for the contaminated site" is defined as meaning:

96(1) In this Part,

(c) "person responsible for the contaminated site" means

(i) a person responsible for the substance that is in, on or under the contaminated site, 
such time as the provincial administering body for the new environment legislation has had an opportunity to decipher and apply this legislation, the full liability impact on the municipality is unknown. In the interval, precautionary steps must be taken by the municipality to shield itself from potential liability.

\section{B. EVADING LIABILITY}

Where property is contaminated to the extent that the possibility of the municipality collecting its taxes has been eliminated, the municipality should divest itself of any interest it may have in the property, either by virtue of the registration of a tax recovery notification or by the acquisition of the fee simple title. ${ }^{145}$ As the contaminated property is a liability, it is impractical to assume that the municipality could re-transfer the property to the taxpayer. Divestiture of title may therefore only be achieved through sale of the property.

In a private sale, the municipality has a duty to the purchaser to disclose the nature and extent of the contamination. ${ }^{146}$ Failure to do so may give rise to liability to the purchaser for misrepresentation. ${ }^{147}$ Even if it is possible to find a purchaser after full disclosure, the municipality may, through its prior ownership and possession, have already attracted liability under the new environment legislation. ${ }^{148}$ Due to these factors, private sale may not be a viable means of evading liability.

(ii) any other person who the Director considers to have been responsible for causing or contributing to the release of the substance into the environment,

(iii) the owner of the contaminated site,

(iv) any previous owner of the contaminated site who was the owner at any time when the substance was in, on or under the contaminated site,

(v) a successor, assignee, executor, administrator, receiver, receiver-manager or trustee of a person referred to in any of subclauses (ii) to (iv), and

(vi) a person who acts as the principal or agent of a person referred to in any of subclauses (ii) to (v).

If the one year time period contained in s. 20(1) has not passed and the municipality becomes aware that the property is contaminated, the municipality should immediately discharge its tax recovery notification. Pursuant to s. 20(1), it is a precondition to the issuing of title to the municipality that a subsisting tax recovery notification be registered against the title to the property. By removing such notification, the tax forfeiture proceedings are extinguished, together with the possible liability associated with the final acquisition of the property. Where the one year time period has passed and the municipality only then becomes aware that the property is contaminated, the municipality, if title has not already been taken, should not take steps to have the title to the property issued in its name. By not becoming the registered owner of the property, and provided the municipality has not taken possession of the property, the municipality could raise the argument that it is not the "owner" or "person responsible for the contaminated site" under the new environment legislation, ibid, and therefore, not responsible for the costs of reclamation. The strength of this argument is yet to be determined. Andrews v. Dupont, [1993] 5 W.W.R. 75 at 81 (Man. Q.B.); and Lerke v. Brear (1990), [1991] 112 A.R. 1 at 10 (Q.B.). 
In order for the municipality to successfully evade liability for contaminated property acquired through tax forfeiture proceedings, evasion would have to start prior to acquisition by the municipality of title or possession to the property. This point in time is dependent upon the continued registration of the tax recovery notification.

Earlier in this article, it was stated that the Act provides that the tax recovery notification cannot be removed unless the treasurer directs its removal or a certificate of title has been issued to the municipality or another person pursuant to the provisions of the $A c t .^{149}$ Since the reason for the registration of the tax recovery notification is the collection of taxes, it is implied that the treasurer will only remove the tax recovery notification upon payment. However, there is no clear directive in the $A c t$ which would require the treasurer to act solely in this manner. ${ }^{150}$

If a municipality chose not to proceed with tax recovery proceedings, then in order for the municipality to comply with the $A c t$, two events must occur. First, the municipality would have to place the property on the tax arrears list and cause a tax recovery notification to be filed. Second, immediately following such registration, the treasurer would have to instruct the Registrar of Land Titles to have the tax recovery notification discharged. Although this procedure may have the effect of safeguarding the municipality from any liability associated with contaminated property, it also eliminates a means for the municipality to collect its taxes. The municipality must therefore look for alternative means of collection.

\section{ALTERNATIVE METHODS OF COLLECTION}

The statutory obligation of the municipality to collect its taxes is mandatory and not permissive. ${ }^{151}$ In E.J.S. Holdings, Prowse J.A. stated this statutory obligation:

The Tax Recovery Act sets out a scheme for recovery of past due taxes and further, it imposes an obligation on the appropriate taxing authorities to enforce payment. Provision is made for the registration against the title of the land, in respect of which taxes are past due, of a tax recovery notification". ${ }^{152}$

This obligation must be carried out without bias or prejudice to a particular taxpayer. ${ }^{153}$ Therefore, the municipality cannot stop the tax forfeiture process in regard to a particular property without resorting to an alternative method of collecting its outstanding taxes.

A possible solution to the problems created by contaminated property and the municipality's statutory duty to collect its taxes may be found in s. 31 of the Act. This

See text accompanying note 11 . Act, supra note 1 at s. 4(5).

See Castor, supra note 75 at 1483 . One might even presume that in the proper circumstances, the municipality could be deemed to have breached its duty as trustee to the general public by not discharging its tax notification and thereby acquiring lands which, as a result of their contaminated state, are a liability and a drain on the public purse.

McCarthy, supra note 26 at 224; Tellier v. Saint-Hyacinthe La Cite De, [1935] S.C.R. 578; Rex ex rel. Larson v. Davison and Calgary (City of), [1936] 3 W.W.R. 23 (Alta. S.C.A.D.).

Supra note 65 at 386.

Morguard, supra note 32 at 506. Compare Norfolk v. Roberts, [1915] 23 D.L.R. 547 at 552 (S.C.C.). 
provision enables a municipality, prior to selling or agreeing to sell the property or becoming the registered owner, to exercise any powers to recover all the arrears of taxes that are given to it by any other statute. Pursuant to ss. 124(1) and 139(1) of the Municipal Taxation Act, ${ }^{154}$ taxes which are due may be recovered by the municipality without resorting to the tax forfeiture process in the Act. ${ }^{155}$

Section 124(1) of the Municipal Taxation Act provides that the taxes and costs due with respect to a property are recoverable by the municipality as a debt due to the municipality from any person who was, or subsequently became the owner, purchaser, lessee, licensee or permittee of the property or a portion thereof. ${ }^{156}$ Additionally, such taxes and costs are a special lien on the estate or interest of such party in the property. ${ }^{157}$

Section 139(1) of the Municipal Taxation Act provides that when taxes are due with regard to a property which is occupied by a tenant, the municipal secretary may give the tenant notice requiring the tenant to pay the tax collector the rent for the premises as it becomes due, up to the amount of the taxes due and unpaid, including costs. The municipal secretary is deemed to have the same authority as the landlord of the property and may collect the rent by distress or otherwise up to the amount of the unpaid taxes and

R.S.A. 1980, c. M-31, [hereinafter Municipal Taxation Act].

It should be noted that ss. 124(1) and 139(1) of the Municipal Taxation Act, ibid. refer to taxes which are due. Section 147 of the Municipal Taxation Act states that taxes are "deemed to be in arrears when they remain unpaid after December 31 of the year in which they were imposed and when taxes are in arrears, the Act applies." As to the application of the Act to tax arrears, see Royal Canadian Legion Norwood (Alberta) Branch 178 v. Edmonton (City of), [1992] 4 Alta. L.R. (3d) 62 (Q.B.), appeal allowed in part, unreported decision dated January 21, 1994 as Appeal No. 9203-0601-AC. It could be argued that the provisions contained in ss. 124(1) and 139(1) apply only to taxes which are due, for example, up to December 31 of the taxation year and are, therefore, unavailable to the municipality in cases involving taxes which are in arrears, (i.e. after December 31 of the taxation year). However, by virtue of the fact that $s .31$ of the Act permits the municipality to resort to any other powers which are given to it in any other statute for the recovery of arrears of taxes due, it would appear that the powers provided by ss. $124(1)$ and 139(1) become revested in the municipality. This issue is yet to be resolved by the courts.

It is unthinkable to suggest that excepting for the previous or present owner of the property, the municipality would have the right to sue the remaining parties as listed in s. 124(1) of the Municipal Taxation Act. However, from a literal reading of s. 124(1), the statutory authority is certainly present. As I was unable to locate any decision which had dealt with this authority regarding these remaining parties, it is unknown as to what reaction to expect from the courts. From my reading of other sections in the Municipal Taxation Act, and in particular s. 3(2)(b), in cases involving exempt property, the municipality is given the right to assess the interest of "an occupant of the property, or part thereof, under a lease, licence or permit" and the interest of any such party is to be assessed in the same manner as if they were the owner of the property. Presumably, the drafters of the legislation wanted to ensure that the right of the municipality to bring an action in debt under s. 124(1) was not to be restricted to the owner and was therefore to include all assessed parties. As s. 124(3) states that the production of a copy of the assessment roll as it relates to the taxes payable by any person is prima facie proof of the debt, it could be concluded that it is a prerequisite to an action under $\mathbf{S}$. 124(1) that such remaining parties have their interests assessed by the municipality. See McMurray Bowling Lid. v. Fort McMurray (New Town of and Alberta Assessment Appeal Board (1979), [1980] 11 Alta. L.R. (2d) 186 at 189 (Q.B.) and Healy Motors Limited v. Edmonton (City of) (1981), [1982] 16 M.P.L.R. 165 at 169 (Alta. Q.B.) for a discussion of the manner of assessing the interests of such remaining parties under s. 3(2)(b).

Municipal Taxation Act, supra note 154 at s. 124(1). 
costs. ${ }^{158}$ As a precondition to the exercise of the remedy provided in s. 139(1), the municipal secretary is required to notify the owner of the property prior to the date when the municipality intends to proceed with the collection of the rent. ${ }^{159}$

The availability to the municipality of the alternative remedy contained in s. 139(1), has not, to date, been judicially considered by the Alberta courts. Other jurisdictions have upheld such right. ${ }^{160}$

With regard to the remedy contained in s. 124(1), it is well-settled law that a tax will not be considered as constituting a debt unless expressly declared to be so by the imposing statute. ${ }^{161}$ In s. 124(1), it is stated that the taxes and costs "are recoverable with interest as a debt due the municipality." This legal requirement would appear to be clearly met by the wording of s. 124(1). It may, therefore, be assumed that a municipality could avail itself of the remedy afforded by s. 124(1) and sue the taxpayer in debt for the taxes due. ${ }^{162}$

In Alberta, the history of municipal taxation discloses that the remedies provided in ss. 124(1) and 139(1) of the Municipal Taxation Act have received little or no use. With the present economic climate, this attitude may soon change. By excluding the municipality from liability associated with contaminated property acquired through tax forfeiture, the use of ss. 124(1) and 139(1) as a means of tax collection may become the commonplace practice, unless the present legislation is amended.

\section{CONCLUSION}

To conclude that the $A c t$ has its shortcomings is a drastic understatement. Unfortunately, mere amendment may not achieve the required remediation. What is needed is new legislation which will embody a new scheme of tax forfeiture. To be successful, this new scheme must enable the collection of taxes, yet safeguard the interests of the taxpayer and other parties interested in the property. Given the confiscatory nature of tax forfeiture, this task may be unrealistic. Notwithstanding this obstacle, it is hoped that the proposed scheme will achieve such a balance. This new scheme would differ from the $A c t$ in the following areas: trust relationship, time of sale, reserve bid, sale price, possession, redemption, private sale and contamination liability.

Because the Act provides the means for collection of taxes through the sale of property, the requirement that the municipality act as a fiduciary vis-à-vis the property may conflict with such an objective. In the Bailey decision, the Court held that the municipality was

Ibid. at s. 139(5).

See Re Lyons and McVeity, [1919] 49 D.L.R. 635 at 637 (Ont. S.C.A.D.).

See the judgment of Stuart J. in Medicine Hat (City of) v. Howson, [1920] 2 W.W.R. 810 at 812 (Alta. S.C.A.D.). See also Gislason v. Foam Lake (Rural Mun. of and Ward (1928), [1929] 1 W.W.R. 233 (Sask. C.A.). 
trustee for the taxpayer with regard to surplus funds which remained after sale of the property. ${ }^{163}$ From the particular facts of Bailey, it is reasonable to assume that a court would hold that a municipality owes a duty of care to ensure that the surplus funds are placed in an interest bearing trust account. Nevertheless, in the majority of cases, the imposition of a trust with regard to forfeited property will effect an unrealistic obligation on the municipality.

Questions involving the extent of this fiduciary duty have already been discussed elsewhere in this article and without answers. It is possible that there may never be satisfactory answers without sacrificing the rights of the municipality or the taxpayer. In order to circumvent the problems which have yet to arise from Bailey, this is one door which should be closed by the new legislation. If the obligations of the municipality to the property and the corresponding rights of the taxpayer are clearly defined in the legislation, there is no need for the imposition of a fiduciary duty. The municipality should therefore be at liberty to offer the property for sale at the public auction to the highest bidder with the reserve bid being equal to the taxes outstanding.

Possession of the property should be available to the municipality at any time after the date of the public auction without conditions regarding occupancy or residency. In cases of residency or occupancy, an order of the court should suffice to protect all parties interested in the property, thereby making the further requirement of ministerial approval unnecessary. Where the municipality has obtained possession, it should have the right to lease the property under any terms it considers advisable. Without restriction by definition, all reasonable costs and expenses incurred by the municipality in the management and disposition of the property should be recoverable by the municipality.

If a property is not sold at the public auction, there should be no deemed final acquisition of the property by the municipality. The municipality should have the sole discretion in determining whether or not it will take title to the property. If the municipality elects to take title, then the alternative remedies contained in ss. 124 and 139 of the Municipal Taxation Act should not be available to the municipality. The property now stands in the place of the indebtedness. However, where the municipality has not taken title and if these alternative remedies prove fruitless, the municipality should not be barred from acquiring the title to the property.

Problems associated with the right of redemption could be curtailed by providing the taxpayer and other parties interested in the property with every opportunity to redeem the property. If title has not been taken by the municipality, the right of redemption should remain available. Redemption should only be prohibited if the municipality has acquired title.

Because the municipality will be required to obtain title to the property in order to transfer the property on a private sale, and because the right of redemption will cease upon the issuance of title, concerns as to when a property is sold are now redundant. The municipality should have the right to sell the property by way of private sale at any time 
after the date of the public auction provided the sale is by public tender. This requirement should eliminate any concerns that the property is being sold at an amount less than its fair market value.

In regard to contaminated property acquired by the municipality through tax forfeiture proceedings, the municipality should be absolved from liability under the new environment legislation. The one exception to such absolution is where the municipality had contributed to the contamination. In cases where the municipality takes title to a contaminated property without prior knowledge of its state, the municipality should be permitted to re-convey the title to the defaulting taxpayer. In these situations, the alternative remedies contained in ss. 124 and 139 of the Municipal Taxation Act should remain available to the municipality.

To permit the scheme of tax forfeiture as embodied in the Act to continue to exist in its present form is to invite litigation. If statutory remediation is not forthcoming, the deficiencies and inefficiencies of the Act may prove catastrophic to both the municipality and the taxpayer. In preventing this occurrence, I hope that the advice and opinions as expressed in this article will be of assistance. 